$\xi^{2}=1$ 줄

\title{
Effects of different post-harvest treatments on bio-chemical characters and diseases of litchi in storage
}

\author{
Fakhar Uddin Talukder ${ }^{1}$, Md. Sohanur Rahman ${ }^{*}$, Md. Kamrul Hassan ${ }^{2}$ \\ ${ }^{1}$ Scientific Officer, Pest Management Division, Bangladesh Jute Research Institute, Dhaka, Bangladesh \\ ${ }^{2}$ Professor, Department of Horticulture, Bangladesh Agricultural University, Mymensingh, Bangladesh \\ *Corresponding author E-mail: sohanbau2010@gmail.com
}

\begin{abstract}
Objective of the study was to evaluate the effects of different post-harvest treatments on bio-chemical characters and diseases of litchi (Litchi chinensis Sonn, var. Bombai). The experiment consisted of two factors. Factor A: Temperature viz. T1: Ambient temperature, T2: $4^{\circ} \mathrm{C}$ temperature; Factor B: PP bags (Polypropylene bag) viz. P1: Control (unwrapped), P2: 50 micro meter ( $\left.\mu \mathrm{m}\right) \mathrm{PP}$ bag, P3: $75 \mu \mathrm{mm}$ PP bag, P4: $100 \mu \mathrm{m}$ PP bag. The experiment was conducted in completely randomized design (CRD) with three replications. Significant variation was observed in total soluble solid, PH of fruit pulp, vitamin c content, percent disease incidence and disease severity during the storage period. TSS contents increased up to the 6th day of storage and there after declined. $\mathrm{pH}$ values were maximum (4.14) in the fruits kept in $100 \mu$ polypropylene bag at ambient temperature. Vitamin C continent decreased with the increase of storage period. Disease incidence and severity progress with the storage period. Among the treated and untreated fruits, $75 \mu \mathrm{m}$ pp bag at low temperature $\left(4^{\circ} \mathrm{C}\right)$ treatment exhibited better storage performance. More research should be conducted by using other litchi cultivar like Bedana, China-3 etc. Various technologies have been devised to minimize the post-harvest losses of litchi, one of such technologies is the use of PP bag \& low temperature.
\end{abstract}

Keywords: Litchi; Low Temperature; Polypropylene Bags; Bio-Chemical Characters and Diseases.

\section{Introduction}

Litchi, a non-climacteric fruit (Wills et al., 2004) belongs to the family Sapindaceae. It is one of the most important fruits of tropical and subtropicalworld and is highly prized for its perfectly blended sweet-acidic juicy pulp (Nusrat Perveen and Hidayatullah Mir, 2019). It deteriorates very fast after harvest. It introduced into Australia, South Africa and Hawaii by the end of the 19th century (Menzel and Simpson, 1986). Qu et al. (2007) reported that red phosphorus fumigation treatment on litchi delayed the increase in polyphenol oxidase activity, $\mathrm{pH}$ value and decreased anthocyanin and phenolies. Semeerbabu et al. (2007) conducted an experiment on litchi fruit treated with $\mathrm{SO}_{2}$ fumigation and followed by $4 \% \mathrm{HCl}$ dip. Ivi \& Dhua (2002) observed that fruits packed in corrugated fiber board with perforated polythene had the highest total soluble solid $\left(16.80^{\circ} \mathrm{Brix}\right)$, total sugar $(13.06 \%)$ and titratable acidity $(0.65 \%)$ than the control fruits after 6 days of storage. Mahajan Goswami (2004) compared the effect of CA (controlled atmosphere 3-5\% $\mathrm{O}_{2}, 3-5 \% \mathrm{CO}_{2}, 95 \% \mathrm{RH}^{2}$ and $2^{\circ} \mathrm{C}$ temp.) and regular atmosphere maintained at $2^{\circ} \mathrm{C}$ temp. and 92-95\% RH. Ghosh et al. (2003) performed an experiment by modified atmosphere packaging and samples treated with $50 \mathrm{ppm} \mathrm{CuSO} 4$ and Borax. These treated fruits shown the maximum acidity $(0.25 \%)$, reducing sugar $(9.18 \%)$, total sugar $(15.86 \%)$ and total soluble solids $\left(16.10{ }^{\circ}\right.$ Brix) after 15 days of storage. Wu et al. (.2001) found that during cold storage total ascorbic acids both in the pericarp and in the juice decreased with the increase in $\mathrm{pH}$ value. In experiments with litchi cv. 'Huaizhi' fruits, a low temperature hardening treatment $\left(5\right.$ days at $\left.5^{\circ} \mathrm{C}\right)$ prior to storage for 40 days at $1^{\circ} \mathrm{C}$ delayed increased in ascorbic acid concentrations after removal from cold storage (Zhang et al. (2000).

Mohajan (1997) studied on the bio-chemical changes in litchi fruits during storage. He observed a declining trend in the titratable acidity of litchi fruit during storage. He added that the titratable acidity varied from 0.41 to $0.3 \%$ during storage. Mitra et al. (1996) found similar trend in change of titratable acid content during storage of litchi fruits. Mitra et al. (1996) carried out an experiment with litchi fruits cv. 'Bomabi' subjected to some postharvest treatments, such as fruits wrapped with perforated polyethylene bags and stored at 0 or $4{ }^{\circ} \mathrm{C}$ and control fruits were dipped in water and stored at ambient temperature and analyzed at 2 days intervals. Similar trend of change in total soluble solid (TSS) during storage of litchi fruit was observed by Nagar (1994).

Liu et al. (2006) evaluated the development of main postharvest diseases in litchi. Korsten (2005) reported that combinations with natural plant extract, soft chemicals and modified atmosphere packaging could provide effective control of Penicillium infection on litchi. A study was conducted by Jiang et al. (2001) to identify the main pathogens of postharvest litchi fruit and evaluate the potential antagonists in vitro. Coates et al. (2003) reported that if fruits are not handled correctly a wide range of fungi like Alternaria, Aspergillus, Fusarium, Cladosporium and Penicillium spp. cause postharvest diseases. The effects of latent infection ( $\geq 90 \%$ infection) of anthracnose fungus Colletotrichum gloeasporiodes on the postharvest physiology of litchi cv. 'Huaizhi' fruits were studied by Liu et al. (2005). 


\section{Materials and methods}

The experiments were carried out at the laboratories of the Departments of Horticulture ,Bangladesh Agricultural University, Mymensingh during the period from 15 May to 15 September, 2016. The litchi variety, namely 'Bombai' was chosen as experimental materials for the current investigation of the experiment. The experimental litchies were collected from the local growers of Ishwardi, Pabna. The maturity of the fruits was determined by the flatness of tubercles and comparative smoothness of epicarp. The commercially important litchi variety namely 'Bombai' was used for the present experiment. The single factor experiment consists of Eight (8) treatments as $\mathrm{T}_{0}=$ control (Fruits under ordinary conditions without wrapping), $\mathrm{T}_{1}=$ Fruits wrapped in $50 \mu$ polypropylene bag at ambient temperature, $T_{2}=$ Fruits wrapped in $75 \mu$ polypropylene bag at ambient temperature, $T_{3}=$ Fruits wrapped in $100 \mu$ polypropylene bag at ambient temperature, $\mathrm{T}_{4}=$ Fruits stored at $4^{\circ} \mathrm{C}$ temperature, $\mathrm{T}_{5}=$ Fruits wrapped in $50 \mu$ polypropylene bag at $4^{\circ} \mathrm{C}$ temperature, $\mathrm{T}_{6}=\mathrm{Fruits}$ wrapped in $75 \mu$ polypropylene bag at $4^{\circ} \mathrm{C}$ temperature and $\mathrm{T}_{7}=$ Fruits wrapped in $100 \mu$ polypropylene bag at $4^{\circ} \mathrm{C}$ temperature. The single factor experiment was laid out in completely randomized design with three replications of 8 fruits. Fruits of more or less similar shape and size and free of visible disease symptoms were randomly selected from the harvested fruits. Among collected fruits in each replication of each treatment 4 fruits were marked to investigate total disease incidence, disease severity, isolation and identification of causal pathogens and the remaining 4 fruits were kept unmarked conditions for destructive sampling to examine TSS, vitamin $\mathrm{C}$ and pulp $\mathrm{pH}$. All the marked and unmarked fruits were then subjected to the following treatments as per the experimental design: Fruits were randomly selected from the lot and kept on brown paper placed on the laboratory floor at ambient conditions without imposing any treatment. Polypropylene bag with the thickness of $50 \mu, 75 \mu$ and $100 \mu(35 \times 24 \mathrm{~cm})$ were used for this treatment. Fruits were kept the Polypropylene bag for each replication. The top of the bag was tied by using thread and then placed on brown paper for observation at ambient condition. Fruits were kept in low temperature $\left(4^{\circ} \mathrm{C}\right)$. Fruits were taken in a petridish and then placed on brown paper for observation at low temperature condition

The fruits into polypropylene bag were kept into refrigerator at temperature of $4{ }^{\circ} \mathrm{C}$. Polypropylene bag with the thickness of $50 \mu, 75 \mu$ and $100 \mu(35 \times 24 \mathrm{~cm})$ were used for this treatment. Fruits were kept the Polypropylene bag for each replication. The top of the bag was tied by using thread and then placed on brown paper for observation at low temperature $\left(4^{\circ} \mathrm{C}\right)$ condition. Parameters were studied as per the following methods:

\subsection{Total soluble solids}

Total soluble solid (TSS) content of litchi pulp was estimated by using Abbe's Refractometer. A drop of litchi juice squeezed from the fruit pulp was placed on the prism of the refractometer. Then TSS was obtained from direct reading of the instrument. Temperature corrections were made by using temperature correction chart that accompanied the instrument.

\subsection{Pulp pH}

Preparation of standard buffer solution pH -7 and pH-4 buffer tablet BDH (chemicals Ltd., Poole, England) was dissolved in water and made up to the mark of $100 \mathrm{ml}$ with distilled water.

\subsubsection{Extraction of fruit juice}

For the determination of pulp $\mathrm{pH}, 5 \mathrm{~g}$ of fresh pulp was taken in a conical flask containing $10 \mathrm{ml}$ of distilled water. Then the pulp was crushed thoroughly in a mortar and pestle and extract was filtered through two layers of cloths.

\subsubsection{Procedure}

The $\mathrm{pH}$ meter (Hannan) was standardized by using buffer solution of $\mathrm{pH}-7$ and $\mathrm{pH}-4$ when correction for temperature was also taken into consideration. On completion of calibration the electrode was washed twice with distilled water, rinsed with litchi juice and dipped into the juice. The $\mathrm{pH}$ was recorded.

\subsection{Vitamin $\mathrm{C}$ content}

Reagents required for the estimation of vitamin C content of litchi pulp were (i) 3\% Metaphosphoric acid (It was prepared by dissolving the sticks of HP03 in distilled water) (ii) Standard ascorbic acid solution and (iii) Dye solution (It was prepared by dissolving $260 \mathrm{mg}$ of sodium salt of 2, 6-dichlorophenol indophenol in 1 litre of distilled water that contained $210 \mathrm{mg} /$ /litre of sodium bicarbonate). The following steps were followed for the estimation of vitamin C:

\subsubsection{Standardization of dye solution}

Five $\mathrm{ml}$ of standard ascorbic acid solution was taken in a conical flask and $5 \mathrm{ml}$ of metaphaspharic acid (HPO3) was added to it and shaken. A micro burette was filled with dye solution. Then the mixed solution was titrated with dye using phenolphthalein indicator solution to a pink coloured end point that persisted at least for 15 seconds. Dye factor was calculated using the following formula:

Dye factor $=\frac{0.5}{\text { litre }}$

\subsubsection{Preparation of sample}

Ten grams of fresh fruit pulp was taken in a $100 \mathrm{ml}$ beaker with $50 \mathrm{ml} 3 \%$ metaphosphoric acid and then it was transferred to a blender and homogenized with same concentration of metaphosphoric acid. After blending, it was filtered and centrifuged at $2000 \mathrm{rpm}$ for 5 minutes. The homogenized liquid was transferred to a $100 \mathrm{ml}$ volumetric flask and was made up to the mark with $3 \%$ metaphosphoric acid. 


\subsubsection{Titration}

Five $\mathrm{ml}$ of the aliquot was taken in a conical flask and titrated with 2,6-dichlorophenol dye. Phenolpthalein was used as indicator to pink coloured end point, which persisted at least 15 seconds. The vitamin $\mathrm{C}$ content of the samples was calculated by using the following formula:

Vitamin $\mathrm{C}$ content $(\mathrm{mg} / 100 \mathrm{~g})=\frac{\mathrm{T} \times \mathrm{D} \times \mathrm{V}_{1}}{\mathrm{~V}_{2} \times \mathrm{W}} \times 100$

Where,

$\mathrm{T}=$ Titre

$\mathrm{D}=$ Dye factor

$\mathrm{V} 1$ = Volume made up

$\mathrm{V} 2=$ Volume of extract

$\mathrm{W}=$ Weight of sample

\subsection{Titratable acidity}

Titratable acidity of litchi pulp was determined according to the method mentioned by Rangana (1979). The following reagents were used for the determination of titratable acidity.

1) Standard $\mathrm{NaOH}$ solution $(0.1 \mathrm{~N})$

2) $1 \%$ phenolphthalein solution

\subsubsection{Extraction of litchi juice}

Ten grams of fresh litchi pulp was homogenized with distilled water in a blender. The blended materials were boiled for 1 hr under refluxing. The whole mass was than cooled, filtered and transferred to a $100 \mathrm{ml}$ volumetric flask and the volume was made up to the mark with distilled water.

\subsubsection{Procedure}

Ten ml pulp solution was taken in a conical flask. Two to three drops of phenolphthalein indicator was added and the flask was shaken vigorously. It was then titrated immediately with $0.1 \mathrm{~N} \mathrm{NaOH}$ solution from a burette till a permanent pink colour was appeared. The volume of $\mathrm{NaOH}$ solution required for titration was noted and percent titratable acidity was calculated by using the following formula:

Percent titratable acidity $=\frac{\mathrm{T} \times \mathrm{N} \times \mathrm{V}_{1} \times \mathrm{E}}{\mathrm{V}_{2} \times \mathrm{W} \times 1000} \times 100$

Where,

T=Titre

$\mathrm{N}=$ Normality of $\mathrm{NaOH}$

$\mathrm{V}_{1}=$ Volume made up

$\mathrm{E}=$ Equivalent weight of acid

$\mathrm{V}_{2}=$ Volume of extract

$\mathrm{W}=$ Weight of sample

\subsection{Disease incidence}

Disease incidence refers to the percentage of fruits infected by disease organisms. The fruits were critically examined every day for the appearance of disease symptoms. The first count was made at the 3rd day of storage. The diseased fruits were identified symptomatically. The disease incidence was calculated as follows:

Disease incidence $(\%)=\frac{\text { Number of infected fruits }}{\text { Total number of fruits under study }} \times 100$

\subsection{Disease severity}

Disease severity refers to the percentage diseased portion of infected fruit. The infected fruits of each replication of each treatment (varieties) were observed to determine percent fruit area infected and was measured based on eye estimation. The mean values regarding infected fruit area were calculated, presented, and discussed.

\subsection{Isolation and identification of causal pathogens}

Representative samples of diseased fruits were collected and taken to the laboratory of the Department of Plant Pathology, Bangladesh Agricultural University, Mymensingh for isolation and subsequent identification of causal organisms. Diseased samples with typical symptoms were selected and ten semi-permanent slides were prepared. Scraping method was used to isolate the organisms. The materials included: diseased fruits samples, slide, cover slip, blade, needle, cotton blue, soft cloth and compound microscope. At first, a clean slide was selected and a drop of cotton blue was placed on the slide. Specimen was collected by scraping with sterilized scalpel blade and was placed on the cotton blue. A cover slip was placed on the specimen. The surrounding area of cover slip was cleaned with soft cloth. A 
total 10 semi-permanent slide were prepared. The prepared slides were observed under compound microscope for identifying the pathogenic structures. After 24 hours the prepared slides were made permanent by using nail polish.

The images of the pathogens were taken by digital camera (Olympus BX51) from the Field Fertility Clinic of Veterinary Science, Bangladesh Agricultural University, Mymensingh. The pathogens were identified as per the descriptions of Mukherji (1972).

\subsection{Observation}

Fruits used in the experiment were observed every day. Data were collected on weight loss, physical and chemical changes and rottening of the fruits during storage as influenced by different postharvest treatments.

\subsection{Statistical analysis}

For the experiment, the collected data were statistically analyzed by Analysis of Variance (ANOVA) test. The means of different parameters were compared by least significant difference (LSD) as described by Gomez and Gomez (1984). For percentage data arcsine transformations were carried out to satisfy the assumption of ANOVA.

\section{Result and discussion}

\subsection{Changes in bio-chemical characters}

Bio-chemical changes, namely total soluble solid, $\mathrm{pH}$ of fruit pulp and vitamin $\mathrm{C}$ content were investigated in the present study. The results are presented and interpreted in the following.

\subsubsection{Total soluble solids}

The storage treatments involved in the present investigation caused significant variation. At the 3rd day of storage, the maximum TSS $\left(19.60^{\circ} \mathrm{Brix}\right)$ was recorded in $\mathrm{T}_{0}$ and minimum TSS $\left(18.10^{\circ} \mathrm{Brix}\right)$ was recorded in $\mathrm{T}_{6}$. Decreases in TSS and TA of litchi are mainly due to respiration that consumes the nutrient substances of fresh litchi (Feng et al., 2011). At day 6 , the maximum TSS (21.2 ${ }^{\circ} \mathrm{Brix}$ ) was recorded in $\mathrm{T}_{0}$ and the minimum TSS $\left(18.80{ }^{\circ} \mathrm{Brix}\right)$ was recorded in $\mathrm{T}_{6}$. At day 9 , the maximum $\mathrm{TSS}\left(20.40{ }^{\circ} \mathrm{Brix}\right)$ was recorded in $\mathrm{T}_{0}$ and the minimum TSS $\left(18.20^{\circ} \mathrm{Brix}\right)$ was recorded in $\mathrm{T}_{2}$ (Fig. 1). The increase in TSS content of fruit pulp with the advancement of storage period reaching a peak at 6th day of storage and decline thereafter and it was supported by Mohajan (1997) and Nagar (1994). Similar result found by Elia Nora Aquino Bolaños et.al.2010.

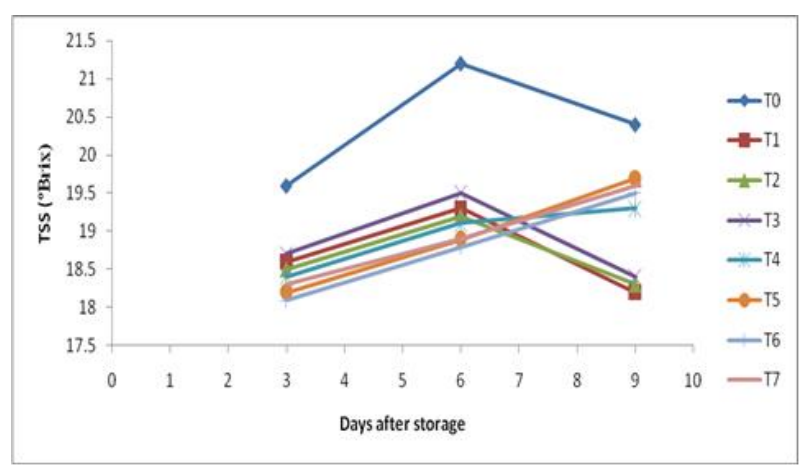

Fig. 1: Effect of Different Postharvest Treatments in Total Soluble Solids of Litchi During Storage. the Vertical Bar Represents LSD at 5\% Level of Probability. $\mathrm{T}_{0}=$ Control, $\mathrm{T}_{1}=50 \mu$ Polypropylene Bag at Ambient Temp, $\mathrm{T}_{2}=75 \mu$ Polypropylene Bag at Ambient Temp, $\mathrm{T}_{3}=100 \mu$ Polypropylene Bag at Ambient Temp, $\mathrm{T}_{4}=$ Low Temperature $\left(4^{\circ} \mathrm{C}\right)$ Treatment, $\mathrm{T}_{5}=50 \mu$ Polypropylene Bag at $4^{\circ} \mathrm{C}$ Temp, $\mathrm{T}_{6}=75 \mu$ Polypropylene Bag at $4{ }^{\circ} \mathrm{C}$ Temp, $\mathrm{T}_{7}=100 \mu$ Polypropylene Bag at $4^{\circ} \mathrm{C}$ Temp.

\subsection{2. pH of fruit pulp}

Variations among the treatments in relation to $\mathrm{pH}$ of fruit pulp were significant as influenced by the postharvest treatment by the postharvest treatments. The maximum (3.80) $\mathrm{pH}$ of fruit pulp was observed in control $\left(\mathrm{T}_{0}\right)$ followed by $\left(\mathrm{T}_{3}\right)$ fruits kept in $100 \mu$ polypropylene

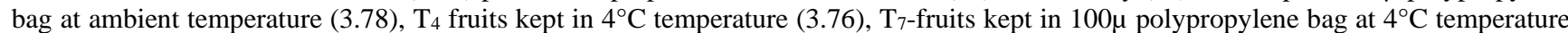
(3.74), T1- fruits kept in 50 $\mu$ polypropylene bag at ambient temperature (3.71), $\mathrm{T}_{2}$ - fruits kept in $75 \mu$ polypropylene bag at ambient temperature (3.67), $\mathrm{T}_{5}$ - fruits kept in $50 \mu$ polypropylene bag at $4{ }^{\circ} \mathrm{C}$ temperature (3.66), and minimum pH value was at $\mathrm{T}_{6}$ - fruits kept in $75 \mu$ polypropylene bag at $4^{\circ} \mathrm{C}$ temperature (3.62) at the 3rd day of storage.Further, it was noticed that the $\mathrm{pH}$ of fruit pulp was gradually increased during the total storage period (Fig. 2). The increase in pulp $\mathrm{pH}$ may be due to continuous falling of acidity during storage. Increased of pulp pH observed in the present study was an agreement with the findings of Tongdee et al. (1982), who found that pulp pH of litchi, increased with storage duration. Similar result was found by Md. Aklimuzzaman et al, 2011. 


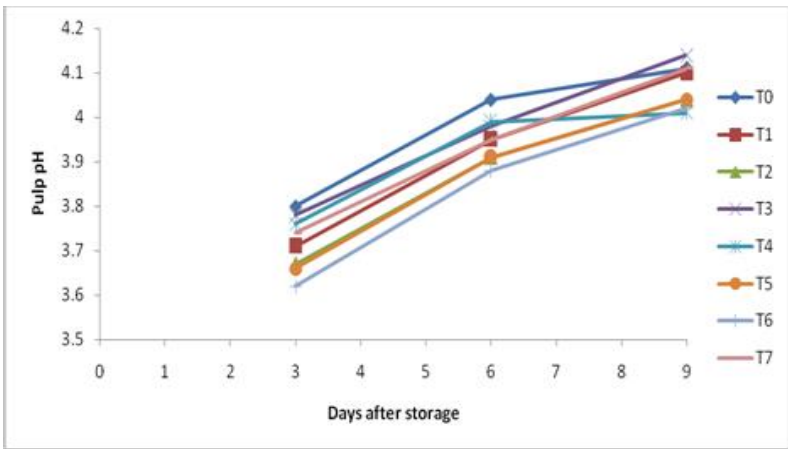

Fig. 2: Effect of Different Postharvest Treatments In Pulp Ph of Litchi During Storage. the Vertical Bar Represents LSD at 5\% Level of Probability. $\mathrm{T}_{0}=$ Control, $\mathrm{T}_{1}=50 \mu$ Polypropylene Bag at Ambient Temp, $\mathrm{T}_{2}=75 \mu$ Polypropylene Bag at Ambient Temp, $\mathrm{T}_{3}=100 \mu$ Polypropylene Bag at Ambient Temp, $\mathrm{T}_{4}=$ Low Temperature $\left(4^{\circ} \mathrm{C}\right)$ Treatment, $\mathrm{T}_{5}=50 \mu$ Polypropylene Bag at $4^{\circ} \mathrm{C}$ Temp, $\mathrm{T}_{6}=75 \mu$ Polypropylene Bag at $4{ }^{\circ} \mathrm{C}$ Temp, $\mathrm{T}_{7}=100 \mu$ Polypropylene Bag at $4^{\circ} \mathrm{C}$ Temp.

\subsubsection{Vitamin $\mathrm{C}$ content}

The postharvest treatments used in the present study in respect of vitamin $\mathrm{C}$ content exhibited highly significant variation among the treatments during storage. Vitamin $\mathrm{C}$ contents declined with the progress of ripening of fruits and it was observed in all tre atments (Table 14). Highest vitamin $\mathrm{C}$ content $(36.02 \mathrm{mg} / 100 \mathrm{~g})$ was in fruits kept in $75 \mu$ polypropylene bag at $4^{\circ} \mathrm{C}$ temperature ( $\left.\mathrm{T}_{6}\right)$ followed by fruits kept in $50 \mu$ polypropylene bag at $4^{\circ} \mathrm{C}$ temperature $\left(\mathrm{T}_{5}\right)(35.73 \mathrm{mg} / 100 \mathrm{~g})$ at the $3 \mathrm{rd}$ day of storage. The lowest vitamin $\mathrm{C}$ contents were in order of $\mathrm{T}_{6}(29.40 \mathrm{mg} / 100 \mathrm{~g})>\mathrm{T}_{7}(28.63 \mathrm{mg} / 100 \mathrm{~g})>\mathrm{T}_{5}(28.17 \mathrm{mg} / 100 \mathrm{~g})>\mathrm{T}_{4}(27.47 \mathrm{mg} / 100 \mathrm{~g})>\mathrm{T}_{2}(22.76 \mathrm{mg} / 100$ $\mathrm{g})>\mathrm{T}_{3}(22.20 \mathrm{mg} / 100 \mathrm{~g})>\mathrm{T}_{1}(21.98 \mathrm{mg} / 100 \mathrm{~g})>\mathrm{T}_{0}(21.34 \mathrm{mg} / 100 \mathrm{~g})$ at the 9 th day of storage as shown in (Table 1). This result is agreement with Xin An Zeng et. al. (2008) and Nettra Somboonkaew, Leon A. Terry. (2010): Among the treatments the $\mathrm{T}_{6}$ (fruits kept in $75 \mu$ polypropylene bag at $4^{\circ} \mathrm{C}$ temperature) treatments was found the most effective in checking the decrease in vitamin $\mathrm{C}$ content of fruit pulp. This result is agreement with Xiaohuang Cao et.al.2019; Lafarga et.al. 2018 and Duan et.al. 2015. Mohajan (1997) stated that vitamin C content decreased during storage period and the present $r$ esult was also a complete agreement with that result. This result was also in complete agreement with the result reported by Mitra et. al. (1996) and Thompson (1975).

Table 1: Effects of Different Postharvest Treatments on Vit $\mathrm{C}$ of Litchi

\begin{tabular}{|c|c|c|c|}
\hline \multirow{2}{*}{ Postharvest treatments } & \multicolumn{3}{|c|}{ Vitamin $\mathrm{C}$ content $(\mathrm{mg} / 100 \mathrm{~g})$ at different days after storage } \\
\hline & 3 & 6 & 9 \\
\hline $\mathrm{T}_{0}$ & 31.14 & 24.14 & 21.34 \\
\hline $\mathrm{T}_{1}$ & 35.22 & 31.45 & 21.98 \\
\hline $\mathrm{T}_{2}$ & 35.53 & 31.97 & 22.76 \\
\hline $\mathrm{T}_{3}$ & 35.35 & 31.02 & 22.20 \\
\hline $\mathrm{T}_{4}$ & 35.18 & 31.26 & 27.47 \\
\hline $\mathrm{T}_{5}$ & 35.73 & 32.19 & 28.17 \\
\hline $\mathrm{T}_{6}$ & 36.02 & 32.94 & 29.40 \\
\hline $\mathrm{T}_{7}$ & 35.50 & 31.96 & 28.63 \\
\hline $\mathrm{LSD}_{0.05}$ & 0.681 & 1.29 & 0.679 \\
\hline $\operatorname{LSD}_{0.01}$ & 0.939 & 1.77 & 0.936 \\
\hline Level of significance & $7.369 * *$ & $23.241 * *$ & $35.822 * *$ \\
\hline
\end{tabular}

$* *=$ Significant at $1 \%$ level of probability, $*=$ Significant at $5 \%$ level of probability, NS $=$ Not significant.

\subsubsection{Titratable acidity}

The varietal difference in terms of titratable acidity was statistically highly significant during storage. Marked reduction was observed in titratable acid content with the advancement of storage period. Titratable acid contents declined up to the $9^{\text {th }}$ day storage for all the treatments. At the $3^{\text {rd }}$ day of storage the maximum acidity was found in those fruits kept in $75 \mu$ polypropylene bag at $4^{\circ} \mathrm{C}$ temperature $(0.50)$, whereas, it was minimum (0.43) in control fruits. At the $6^{\text {th }}$ day of storage the maximum acidity was found in those fruits kept in $75 \mu$ polypropylene bag at $4^{\circ} \mathrm{C}$ temperature $(0.39)$, whereas, it was minimum $(0.25)$ in control fruits. At the $9^{\text {th }}$ day of storage the maximum acidity was found in those fruits kept in $75 \mu$ polypropylene bag at $4^{\circ} \mathrm{C}$ temperature $(0.30)$, whereas, it was minimum (0.19) in control fruits (Table 2). In the present investigation, decrease in percent titratable acidity observed during storage agrees with the results of Mahajan (1997) and Mitra et al (1996). The decrease in titratable acidity during storage may be attributed to the utilization of organic acids in respiratory process and other biodegradable reactions (Ulrich, 1974). Decreases in TSS and TA of litchi are mainly due to respiration that consumes the nutrient substances of fresh litchi (Feng et al., 2011). This result is agreement with Sai Xu, et.al. 2019 and Elia Nora Aquino Bolaños et.al.2010.

Table 2: Effects of Different Postharvest Treatments on Titratable Acidity of Litchi

\begin{tabular}{llll}
\multicolumn{2}{c}{ Table 2: Effects of Different Postharvest Treatments on Titratable Acidity of Litchi } \\
\hline \multirow{2}{*}{ Postharvest treatments } & \multicolumn{2}{c}{ Titratable acidity at different days after storage } & \multicolumn{1}{c}{} \\
& 3 & 0.25 & 0 \\
\hline $\mathrm{T}_{0}$ & 0.44 & 0.35 & 0.19 \\
$\mathrm{~T}_{1}$ & 0.45 & 0.33 & 0.30 \\
$\mathrm{~T}_{2}$ & 0.45 & 0.32 & 0.25 \\
$\mathrm{~T}_{3}$ & 0.46 & 0.31 & 0.28 \\
$\mathrm{~T}_{4}$ & 0.45 & 0.36 & 0.25 \\
$\mathrm{~T}_{5}$ & 0.49 & 0.37 & 0.28 \\
$\mathrm{~T}_{6}$ & 0.50 & 0.35 & 0.29 \\
$\mathrm{~T}_{7}$ & 0.48 & 0.05 & 0.27 \\
$\mathrm{LSD}_{0.05}$ & 0.08 & 0.08 & 0.05
\end{tabular}


Level of significance $\quad 0.001 \mathrm{NS} \quad 0.004 * \quad 0.004 *$

$* *=$ Significant at $1 \%$ level of probability, $*=$ Significant at $5 \%$ level of probability, NS = Not significant.

\subsection{Postharvest disease}

\subsubsection{Disease incidence}

The postharvest storage treatments used in the present study had marked effect on disease incidence of litchi fruits. The var iation among the treatments mean in terms of disease incidence were significant except the 2 nd day of storage. At the 10 th day of storage, maximum (100\%) disease incidence was observed in the control $\left(\mathrm{T}_{0}\right)$ fruits and also on the fruits kept in $100 \mu$ polypropylene bag at ambient temperature. The most of the disease incidence occurs in $\mathrm{T}_{3}(100 \mu$ polypropylene bag at ambient temperature) treatment (Table 3). In case of all treatments disease incidence were increased with the storage period. The lit chi fruits that were kept in $100 \mu$ polypropylene bag at ambient temperature $\left(\mathrm{T}_{3}\right)$ and the control fruits $\left(\mathrm{T}_{\mathrm{I}}\right)$ showed an incidence level of $40.00 \%$ and $46.67 \%$ at the 4th day of storage, respectively, which sharply increased up to $100 \%$ at the $10^{\text {th }}$ day of storage. On the contrary, There is no disease incidence occurs in all the fruits kept in $4^{\circ} \mathrm{C}$ temperature $\left(\mathrm{T}_{4}, \mathrm{~T}_{5}, \mathrm{~T}_{6}, \mathrm{~T}_{7}\right)$ treatments.

Table 3: Effects of Different Postharvest Treatments on Percent Disease Incidence of Litchi

\begin{tabular}{|c|c|c|c|c|}
\hline \multirow{2}{*}{ Postharvest treatments } & \multicolumn{4}{|c|}{ \% Disease incidence at different days after storage } \\
\hline & 2 & 4 & 6 & 8 \\
\hline $\mathrm{T}_{0}$ & 20.00 & 46.67 & 66.67 & 100.00 \\
\hline $\mathrm{T}_{1}$ & 7.33 & 33.33 & 53.33 & 80.00 \\
\hline $\mathrm{T}_{3}$ & 26.67 & 40.00 & 60.00 & 100.00 \\
\hline $\mathrm{T}_{4}$ & 0.00 & 0.00 & 0.00 & 0.00 \\
\hline $\mathrm{T}_{5}$ & 0.00 & 0.00 & 0.00 & 0.00 \\
\hline $\mathrm{T}_{6}$ & 0.00 & 0.00 & 0.00 & 0.00 \\
\hline $\mathrm{T}_{7}$ & 0.00 & 0.00 & 0.00 & 0.00 \\
\hline $\mathrm{LSD}_{0.05}$ & 0.61 & 12.24 & 12.24 & 7.70 \\
\hline $\mathrm{LSD}_{0.01}$ & 0.84 & 16.86 & 16.86 & 10.61 \\
\hline Level of significance & $343.079 * *$ & $1247.619 * *$ & $2847.619 * *$ & $6780.952 * *$ \\
\hline
\end{tabular}

\subsubsection{Disease severity}

There was variation in disease severity level during storage. Maximum $(51.67 \%)$ disease severity was observed in control $\left(\mathrm{T}_{0}\right)$ fruits (Table.4), while minimum $(0.00 \%)$ was observed in the fruits kept in $4^{\circ} \mathrm{C}$ temperature $\left(\mathrm{T}_{4}\right), 50 \mu$ polypropylene bag at $4^{\circ} \mathrm{C}$ temperature $\left(\mathrm{T}_{5}\right), 75 \mu$ polypropylene bag at $4^{\circ} \mathrm{C}$ temperature, $100 \mu$ polypropylene at $4^{\circ} \mathrm{C}$ temperature $\left(\mathrm{T}_{7}\right)$ at the $10^{\text {th }}$ storage period. Disease severity increases with the increase of storage period. All the fruits kept in $4^{\circ} \mathrm{C}$ temperature $\left(\mathrm{T}_{4}, \mathrm{~T}_{5}, \mathrm{~T}_{6}, \mathrm{~T}_{7}\right)$ showed no disease severity at all the storage period. The fruits remain in ambient condition $\left(\mathrm{T}_{0}\right)$ showed a sharp increase in percent severity during the entire storage period but it was slower in the fruits kept in $75 \mu$ polypropylene bag at ambient temperature $\left(\mathrm{T}_{2}\right)$ treatment and it was $13.33 \%$ at the $10^{\text {th }}$ day of the storage period.

Table 4: Effects of Different Postharvest Treatments on Percent Disease Severity of Litchi

\begin{tabular}{|c|c|c|c|c|}
\hline \multirow{2}{*}{ Postharvest treatments } & \multicolumn{4}{|c|}{ Disease severity (\%) at different days after storage } \\
\hline & 2 & 4 & 6 & 8 \\
\hline $\mathrm{T}_{0}$ & 1.00 & 10.00 & 25.67 & 51.67 \\
\hline $\mathrm{T}_{1}$ & 0.00 & 5.06 & 12.33 & 19.67 \\
\hline $\mathrm{T}_{2}$ & 0.00 & 1.33 & 7.04 & 13.33 \\
\hline $\mathrm{T}_{3}$ & 0.00 & 8.67 & 17.67 & 30.67 \\
\hline $\mathrm{T}_{4}$ & 0.00 & 0.00 & 0.00 & 0.00 \\
\hline $\mathrm{T}_{5}$ & 0.00 & 0.00 & 0.00 & 0.00 \\
\hline $\mathrm{T}_{7}$ & 0.00 & 0.00 & 0.00 & 0.00 \\
\hline $\mathrm{LSD}_{0.05}$ & 0.87 & 1.38 & 1.51 & 0.87 \\
\hline $\mathrm{LSD}_{0.01}$ & 1.19 & 1.91 & 2.08 & 1.19 \\
\hline Level of significance & $53.160 * *$ & $291.943 * *$ & $1076.623 * *$ & $53.160 * *$ \\
\hline
\end{tabular}

$* *$ = Significant at $1 \%$ level of probability.

\subsubsection{Isolation and identification of pathogens}

Disease starts on fruit skin and gradually expands all over the fruits. Initially small spots were observed, then the spots were enlarged and several spots coalesced together to produce large lesion. Finally, white cottony fungal mycelia developed on the fruit surface in case of serious infection. A wide range of fungi can cause decay of litchi fruit (Holcroft and Mitcham 1996; Jiang et al. 2003). The main pathogen isolated from litchi was identified as Peronophythora litchi (Jiang et al. 2001).

Infected fruits were picked up from the different treatments and were studied at the laboratory of the Department of Plant Pathology Laboratory of Bangladesh Agricultural University, Mymensingh for identifying the causal organisms. Ten semi-permanent slides were prepared from the diseased fruits. In case of 'Bombai' variety were found infected by Rhizopus and Penicillium spp. The characteristics of the causal pathogens are as follows:

- Rhizopus spp.

From the microscopic observation it appears that this pathogen produced sac like and globosely structure called sporangium (Plate A). 1t bears a dome shaped persistent structure named by columella. A root like structure called rhizoid was also present beneath the sporangipohare. This was also reported by Mukherji (1972). 
- $\quad$ Penicillium spp.

The pathogen was identified based on the sexual reproductive structures called conidia. Conidia are unicellular, globose to ovoid (Plate B). On the top of the sterigmeta conidia produce a conidial chain and similar structure was also observed by Mukherji (1972) and de Jager et al. 2003. Dharini Sivakumar et al. (2007) also isolated Penicillium spp. of storage litchi. Similar disease was identified by Vinod Kumar (2011).
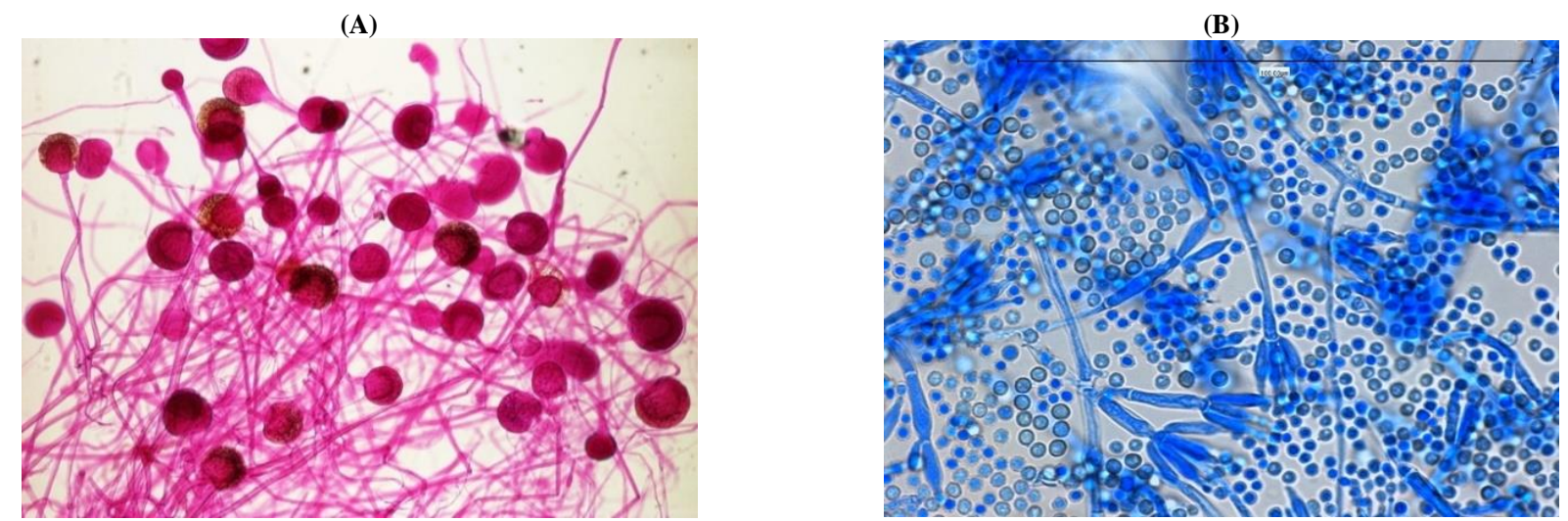

Plate. 1: Microscopic View (X80) of Isolated Pathogens (A: Rhizopus Sp. and B: Penicillum Sp) From Infected Litchi Fruits.

\section{Conclusion}

Significant variation was observed in total soluble solid, $\mathrm{PH}$ of fruit pulp, vitamin c content, percent disease incidence and disease severity during the storage period. But TSS contents were always higher in the fruits of $100 \mu$ polypropylene bag at ambient temperature as compared to the others. $\mathrm{pH}$ value increase up to 6th day of storage. Vitamin $\mathrm{C}$ continent decreased with the increase of storage period. Minimum $(0.00 \%)$ disease severity and $(0.00 \%)$ disease incidence was observed in fruits treated with low temperature with or without polypropylene bag at all the time period of storage.Considering the above discussion it may be concluded that keeping litchi in $75 \mu$ polypropylene bag and stored in low temperature $\left(4^{\circ} \mathrm{C}\right)$ is the best to extend its storage without affecting the quality.

\section{Acknowledgement}

Authors are grateful to the ministry of science and technology, Bangladesh for providing financial support to conduct the research work.

\section{Conflict of interest}

The authors have no conflict of interest to report.

\section{References}

[1] Coates L M, Sangchote S, Johnson G I and Sittigul C (2003) Diseases of longan, lychee and rambutan. Diseases of tropical crops, 307-325. https://doi.org/10.1079/9780851993904.0307.

[2] de Jager ES \& Korsten L (2003) Effect of fungicides and disinfectants in the prevention of litchi pericarp browning and control of postharvest diseases. South African Litchi Growers' Association Yearbook 15, 16-21.

[3] Dharini Sivakumar, Lise Korsten \& Karin Zeeman (2007) Postharvest Management on Quality Retention of Litchi during Storage, Fresh Produce,Global Science Books. https://doi.org/10.2212/spr.2008.3.2.

[4] Duan X, Huang L L Wang M M, Qiao F \& Fang C F (2015) Studies on the effects of microwave power and temperature control on the quality of whole lychee (Litchi chinensis Sonn.) fruit during microwave vacuum drying. J. Food Process. Preserv. 39, 423-43. https://doi.org/10.1111/jfpp.12247.

[5] Elia Nora Aquino Bolaños, Ruben Corona Velázquez, Andrés Villegas Cárdenaz, Isabel Reyes Santamaría , Norma Güemes Vera, Alma Delia Hernandez Fuentes \& Edmundo Mercado Silva (2010) Effect Of Storage Temperature And Time On Quality In Minimally Processed Litchi Fruit (Litchi Chinensis Sonn.), Journal of Food Quality 33, 299-311. https://doi.org/10.1111/j.1745-4557.2010.00324.x.

[6] Feng C, B Liu \& Q Xiao (2011) Comparative study on postharvest quality of different litchi cultivars in hainan. Chinese Journal of Tropical Crops 6,1046-1050.

[7] Ghosh B, Biswas B, Mitra S K \& Bose TK (1987) Physico-chemical composition of some litchi cultivars. Indian Food Pack, 41: 34-37.

[8] Gomez K A \& Gomez A A (1984) Statistical Procedures for Agriculture Research. John Weley and Sons. Inc., New York, pp. 67-265.

[9] Holcroft D M, Mitcham E J (1996) Postharvest physiology and handling of litchi (Litchi chinensis Sonn.). Postharvest Biology and Technology 9, 265- 281. https://doi.org/10.1016/S0925-5214(96)00037-3.

[10] Ivi C \& Dhua R S (2002). Retention of fruit quality of ambient stored litchi (Litchi chinensis Sonn.) cv. 'Bombai' as influenced by different packaging materials. Hort. J, 15 (1): 41-46. https://doi.org/10.5958/2249-5258.2017.00006.9.

[11] Jiang YM, Yao L \& Lichter A, Li J (2003) Postharvest biology and technology of litchi fruit. Food, Agriculture and Environment 2, 76-81.

[12] Jiang YM, Zhu X R \& Li YB (2001) Postharvest control of litchi fruit rot by Bacillus subtilis. Lebeussittel Wissenschaft Technologies, 34(7): 430436. https://doi.org/10.1006/fstl.2001.0758.

[13] Korsten L (2005) Advances in control of postharvest diseases in tropical fresh produce. Proc. Microbiology Conf. on Postharvest Tech. and Quality Management in Arid Tropics, Sultanate of Oman, 31 January-2 February 2005, pp 163-170.

[14] Lafarga T, Bobo G, Vinas I, Zudaire L, Simo J \& Aguilo-Aguayo I (2018) Steaming and sous-vide: Effects on antioxidant activity, vitamin C, and total phenolic content of Brassica vegetables. Int. J. Gastron. Food Sci.13, 134-139. https://doi.org/10.1016/j.ijgfs.2018.05.007.

[15] Liu A Y, Chen W \& Li XY (2006) Development of anthracnose on harvested litchi fruits and the effects of the disease on storage of the fruits. Acta Phytophylacia Sinica, 33(4): 351-356. 
[16] Liu AY, Chen W \& Li X Y (2005) Changes in the postharvest physiology and lychee fruits latently infected by anthrucnose fungus and the biological characteristics of the pathogenic fungus of the disease. Acta Hort., 665:365-371. https://doi.org/10.17660/ActaHortic.2005.665.45.

[17] Mahajan PV \& Goswami T K (2004) Extended storage life of litchi fruit using controlled atmosphere and low temperature. J. Food Process. Preserv., 28(6): 386-403. https://doi.org/10.1111/j.1745-4549.2004.21127.x.

[18] Md Aklimuzzaman, Chayon Goswami, Jewel Howlader, Hafij Al Kader \& Md. Kamrul Hassan (2011) Postharvest storage behavior of litchi. JOURNAL of Horticulture, Forestry and Biotechnology, Volume 15(3), $1-8$.

[19] Menzel CM \& Simpson D R (1986) Lychee cultivars. Queensland Agril. J., 112(3): 125-136.

[20] Mitra S, Harangi A B S \& Kar N (1996) Effect of polyethylene at low temperature on changes in total soluble solids, total sugar, titratable acidity and ascorbic acid content of litchi (cv. 'Bambai') during storage. Environ. Eeol., 14(3):538-542.

[21] Mohajan BVC (1997) Studies on the bio-chemical changes in litchi fruits during storage. Indian J. Plant Physiol., 2(4): $310-31$ 1.

[22] Mukherji H (1972) Plant groups. New Central Bk. Agency (8th ed), Calcutta, pp. 251-276.

[23] Nagar P K (1994) Physiological and biochemical studies during fruit ripening in litchi (Litchi chinensis Sonn.). Postharvest Biol. Technol.,4(3):255-234. https://doi.org/10.1016/0925-5214(94)90032-9.

[24] Nettra Somboonkaew \& Leon A Terry (2010) Physiological and biochemical profiles of imported litchi fruit under modifiedatmosphere packaging, Postharvest Biology and Technology, 56, 246-253. https://doi.org/10.1016/j.postharvbio.2010.01.009.

[25] Nusrat Perveen \& Hidayatullah Mir (2019) Pericarp browning in litchi: A major bane to the blessed fruit, Indian Farmer 6(5): 335 -339.

[26] Qu H, Desen K, Li Y \& Jiang Y (2007) Effectives of red phoshphorus fumigation on browning and quality of postharvest litchi (litchi chinensis Sonn), Fruit J. Food Sci. Technol., Mysore, 44(2): 154-157. https://doi.org/10.1016/0925-5214(94)00021-J.

[27] Sai Xu, Huazhong Lu \& Xiuxiu Sun (2019) Quality Detection of Postharvest Litchi Based on Electronic Nose: A Feasible Way for Litchi Fruit Supervision during Circulation Process, HORTSCIENCE • https://doi.org/10.21273/HORTSCI14750-19.

[28] Semeerbabu M T, Kudachikar V B, Revathy B, Ushadevi A, Matche RS \& Ramana KVR (2007) Effect of postharvest treatments on shelf life and quality of litchi fruit stored under modified atmosphere at low temperature. J. Food Sci. Technol., Mysore, 44(1): 106-109.

[29] Thompson S D (1975) A progress Report on Handling and Storage of Fresh Lychees. Florida Lychees Grower's Assoc. Yearbook, 2:27-28.

[30] Tongdee SC, Scott KJ \& McGlasson WB (1982) Packaging storage of litchi fruit, CSIRO Food Res. Quarl., 42(2): 25-28. [Cited from Hort. Abst. 54(1): 38, 1984].

[31] Ulrich R (1974) Organic acids. In: Biochemistry of fruits and their products Ed. A.C. Hulme. Academic press, New York. Pp. 89-118.

[32] Vinod Kumar, Amrendra Kumar \& Vishal Nath (2011) Emerging pests and diseases of litchi (Litchi chinensis Sonn.), Pest Management in Horticultural Ecosystems, Vol. 17, No. 1, pp 11-13. https://doi.org/10.17660/ActaHortic.2014.1029.53

[33] Wills R H H, Lee T H, Graham D, McGlasson W B \& Hall E G (2004) Post harvest. An Introduction to the physiology and Handing of Fruits and Vegetables. Granada Publ. Ltd. London, pp. 161.

[34] Wu Z X, Su M X, Ji Z I, Chen WX, Han D M, Huang H B \& Menzel C (2001) A study of the behavior of 'Feizixiao' litchi during st orage. Acta Hort., 558: 381-386. https://doi.org/10.17660/ActaHortic.2001.558.61.

[35] Xiaohuang Cao, Jianping Chen, Md. Nahidul Islam Wanxiu Xu \& Saiyi Zhong. (2019) Effect of Intermittent Microwave Volumetric Heating on Dehydration, Energy Consumption, Antioxidant Substances, and Sensory Qualities of Litchi Fruit during Vacuum Drying, Molecules , 24, 4291; https://doi.org/10.3390/molecules24234291.

[36] Xin An Zeng, Xiao Dong Chen, Frank G F Qin \& Lu Zhang (2008) Composition Analysis of Litchi Juice and Litchi Wine, International Journal of Food Engineering, Volume 4, Issue 4, Article 7, https://doi.org/10.2202/1556-3758.1379.

[37] Zhang D L, Quantick P C, Herregods M, Nicolai B, Jager A D \& Roy SK (2000) Effect of low temperature hardening on postharvest storage of litchi fruit. Acta Hort., 518-182. https://doi.org/10.17660/ActaHortic.2000.518.23. 